\title{
Southern Armyworm, Spodoptera eridania (Cramer) (Insecta: Lepidoptera: Noctuidae) ${ }^{1}$
}

J. L. Capinera ${ }^{2}$

\section{Distribution}

This insect is native to the American tropics, occurring widely in Central and South America and the Caribbean. In the United States, the southern armyworm is found principally in the southeastern states; its range extends as far west as Kansas and New Mexico. It also is reported from California, but is of no consequence there.

\section{Life Cycle and Description}

The number of generations is estimated at four annually in Florida. In northern Florida moths can be found throughout the year, withstanding several days of freezing weather (Mitchell and Tumlinson 1994).

About 30 to 40 days is required for a complete generation.

\section{Eggs}

The shape of the eggs is a flattened sphere. Eggs measure about $0.45 \mathrm{~m}$ in diameter and $0.35 \mathrm{~mm}$ in height. The eggs are greenish initially, turning tan as they age. Eggs are laid in clusters, and covered with scales from the body of the moth. Duration of the egg stage is four to six days.

\section{Larvae}

The larvae undergo six instars as they grow to attain a length of about $35 \mathrm{~mm}$. The head capsule widths are about $0.25-0.30,0.40-0.50,0.60-0.80$, $0.95-1.15,1.35-1.85$, and $2.35-2.85 \mathrm{~mm}$, respectively (Redfern 1967). Larvae are green or blackish green with a uniform light brown or reddish brown head throughout the period of development. Larger larvae bear a narrow white line dorsally, and additional stripes laterally. Each side normally bears a broad yellowish or whitish stripe that is interrupted by a dark spot on the first abdominal segment, although in some cases this spot is weak. A series of dark triangles is usually present dorsolaterally along the length of the body. Larvae usually are found on the lower surface of leaves, and are most active at night. Duration of the larval stage is normally 14 to 20 days.

\section{Pupae}

Larvae pupate in the soil, usually at a depth of $5-10 \mathrm{~cm}$. The pupae are mahogany brown in color and measure about 16 to $18 \mathrm{~mm}$ in length and 5 to $6 \mathrm{~mm}$ in width. Duration of the pupal period is 11 to 13 days.

1. This document is EENY-106, one of a series of the Entomology and Nematology Department, Florida Cooperative Extension Service, Institute of Food and Agricultural Sciences, University of Florida. Original publication date August 1999. Reviewed May 2003. Visit the EDIS Web Site at http://edis.ifas.ufl.edu.

2. J. L. Capinera, professor/chairman, Entomology and Nematology Department, Cooperative Extension Service, Institute of Food and Agricultural Sciences, University of Florida, Gainesville, FL 32611.

The Institute of Food and Agricultural Sciences (IFAS) is an Equal Opportunity Institution authorized to provide research, educational information and other services only to individuals and institutions that function with non-discrimination with respect to race, creed, color, religion, age, disability, sex, sexual orientation, marital status, national origin, political opinions or affiliations. U.S. Department of Agriculture, Cooperative Extension Service, University of Florida, IFAS, Florida A. \& M. University Cooperative Extension Program, and Boards of County Commissioners Cooperating. Larry Arrington, Dean 


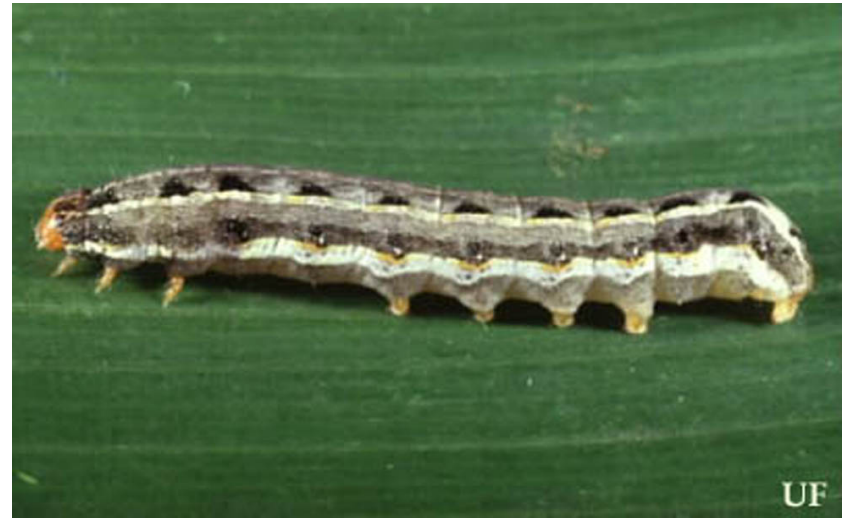

Figure 1. Mature larva of the southern armyworm, Spodoptera eridania (Cramer). Credits: John L. Capinera, University of Florida

\section{Adults}

The moths measure 33 to $38 \mathrm{~mm}$ in wing span. The forewings are gray and brown, with irregular dark brown and black markings. The wing pattern is highly variable, some individuals bearing a pronounced bean-shaped spot near the center of the wing whereas others lack the spot or instead bear a broad black band extending from the center of the wing to the margin. The hind wings are opalescent white.

The biology of the southern armyworm is poorly documented, but Chittenden and Russell (1910) give key features. Additional description is given by Crumb (1929). The key presented by Levy and Habeck (1976) is useful for distinguishing southern armyworm from related species. A sex pheromone has been identified and evaluated in the field (Mitchell and Tumlinson 1994).

\section{Host Plants}

This species has a very broad host range, and includes important vegetable, fruit, field and ornamental crops. Among of the vegetables injured are beet, cabbage, carrot, collard, cowpea, eggplant, okra, pepper, potato, sweet potato, tomato, and watermelon. Other crops damaged include avocado, citrus, peanut, sunflower, velvet bean, tobacco and various flowers. Many weeds are consumed, but pigweed, Amaranthus spp.; and pokeweed, Phytolacca americana; are especially favored. Grasses are rarely eaten. There are numerous reports of armyworm infestations beginning with pigweed and pokeweed, with adjacent crops damaged only after the more favored weeds are consumed.

\section{Damage}

Larvae are defoliators and feed gregariously while young, often skeletonizing leaves. As they mature they become solitary, and also bore readily into fruit, often damaging tomato in Florida. When stressed by a lack of food they will eat the apical portions of branches, bore into stem tissue, and attack tubers near the surface of the soil.

\section{Natural Enemies}

Several wasps parasitoids commonly associated with caterpillars of other species, including Cotesia marginiventris (Cresson), Chelonus insularis Cresson, Meteorus autographae Muesebeck, and $M$. laphygmae Viereck (all Hymenoptera: Braconidae) also attack southern armyworm. Meteorus autographae was the dominant parasitoid in a Florida study (Tingle et al. 1978). Also reared from southern armyworm are Campoletis flavicincta (Ashmead) and Ophion flavidus Brulle (both Hymenoptera: Ichneumonidae); Euplectrus platyhypenae Howard (Hymenoptera: Eulophidae); Choeteprosopa hedemanni Braeur and Bergenstamm, Euphorocera claripennis (Macquart), Gonia crassicornis (Fabricius), Winthemia quadripustulata (Fabricius), and W. rufopicta (Bigot) (all Diptera: Tachinidae).

Undoubtedly predatory insects such as stink bugs (Hemiptera: Pentatomidae) prey on southern armyworm, but this seems to be undocumented. Larvae also are susceptible to infection by the fungus Beauveria bassiana (Gardner and Noblet 1978).

\section{Management}

Southern armyworm is best controlled with foliar insecticides when larvae are small. Insecticides vary considerably in their toxicity to larvae, and is difficult to control with botanical insecticides. Berger (1920) reported some success at southern armyworm suppression by application of bran bait containing insecticide. However, this is primarily useful for large, mobile larvae that have left the plant and are on the soil surface. For specific chemical recommendations see: 
Insect Management Guide for Vegetables

Insect Management Guide for Field Crops

\section{Selected References}

Berger, E.W. 1920. The semitropical armyworm. State Plant Board of Florida Quarterly Bull. 4:17-31.

Capinera, J.L. 2001. Handbook of Vegetable Pests. Academic Press, San Diego. 729pp.

Chittenden, F.H. and H.M. Russell. 1910. The semitropical armyworm. USDA Bur. Entomol. Bull. 66:53-70.

Crumb, S.E. 1929. Tobacco cutworms. USDA Tech. Bull. 88. 179 pp.

Gardner, W.A. and R. Noblet. 1978. Effects of host age, route of infection, and quantity of inoculum on the susceptibility of Heliothis virescens, Spodoptera eridania, S. frugiperda to Beauveria bassiana. J. Georgia Entomol. Soc. 13:214-222.

Levy, R. and D.H. Habeck. 1976. Descriptions of the larvae of Spodoptera sunia and S. latifascia with a key to the mature Spodoptera larvae of the eastern United States (Lepidoptera: Noctuidae). Ann. Entomol. Soc. Am. 69:585-588.

Mitchell, E.R. and J.H. Tumlinson. 1994. Response of Spodoptera exigua and S. eridania (Lepidoptera: Noctuidae) males to synthetic pheromone and S. exigua females. Florida Entomol. 77:237-247.

Redfern, R.E. 1967. Instars of southern armyworm determined by measurement of head capsule. J. Econ. Entomol. 60:614-615.

Tingle, F.C., T.R. Ashley, and E.R. Mitchell. 1978. Parasites of Spodoptera exigua, S. eridania (Lep.: Noctuidae) and Herpetogramma bipunctalis (Lep.: Pyralidae) collected from Amaranthus hybridus in field corn. Entomophaga 23:343-347. 